\title{
Homologous and heterologous in vitro regulation of pig pituitary somatostatin receptor subtypes, sst1, sst2 and sst5 mRNA
}

\author{
R M Luque ${ }^{1,2}$, S Park², X-D Peng ${ }^{2}$, E Delgado', F Gracia-Navarro', R D Kineman², \\ M M Malagón ${ }^{1}$ and J P Castaño ${ }^{1}$ \\ ${ }^{1}$ Department of Cell Biology, Physiology and Immunology, University of Córdoba, Córdoba, Spain \\ ${ }^{2}$ Department of Medicine, University of Illinois at Chicago, Chicago, Illinois, USA \\ (Requests for offprints should be addressed to J P Castaño, Department of Cell Biology, Physiology and Immunology, Edificio Severo Ochoa, \\ Planta 3, Campus de Rabanales, University of Córdoba, E-14014 Córdoba, Spain; Email: justo@uco.es)
}

\begin{abstract}
Somatostatin (SRIF) is commonly regarded as an inhibitor of GH release in rodents and humans. However, in pigs, SRIF can stimulate the release of GH at low (picomolar) doses, while inhibiting GHRH-stimulated GH release at high (nanomolar) doses in primary pituitary cell cultures. One possible mechanism by which pig cells respond differently to the actions of SRIF is by differential expression and regulation of SRIF receptor subtypes. As no information is available on the homologous regulation of SRIF receptors in pigs, we examined the acute $(4 \mathrm{~h})$ in vitro effects of SRIF on mRNA levels of SRIF receptors sst 1 , sst2 and sst 5 by multiplex RT-PCR. These particular sst subtypes were selected because all three have been implicated in the inhibitory effects of SRIF on GH release in both rodents and humans. At a high dose $\left(10^{-7} \mathrm{M}\right)$, SRIF stimulated the expression of sst1, sst2 and sst5 in pig pituitary cell cultures. At a low dose $\left(10^{-13} \mathrm{M}\right)$, SRIF markedly increased sst1, without affecting sst2 or sst5. Given that our laboratory has shown SRIF at high and low doses stimulates cAMP production in a subpopulation of pig somatotropes, we sought to determine if this signaling pathway may be responsible for the stimulatory effect of SRIF on its own receptor expression. The receptor-independent cAMP activator forskolin elevated sst 1 and sst2 mRNA levels but did not affect sst5 expression, suggesting the stimulatory actions of high- and low-dose SRIF on sst1 and high-dose SRIF on sst2 mRNA levels can be mediated by activation of cAMP, whereas the stimulatory effect of high-dose SRIF on sst5 mRNA is elicited by a cAMP-independent pathway. Interestingly, both GHRH $\left(10^{-8} \mathrm{M}\right)$ and ghrelin $\left(10^{-6} \mathrm{M}\right)$, which release $\mathrm{GH}$ in pig pituitary cell cultures via cAMP-dependent mechanisms, decreased sst5 without altering sst1 or sst2 mRNA levels. Since the actions of GHRH and ghrelin on sst expression markedly contrasted with that observed for SRIF and forskolin these results clearly indicate GHRH and ghrelin are regulating sst5 mRNA levels by a cAMP-independent signaling pathway. Taken together, our results demonstrate that expression of pig SRIF receptors is under a complex, receptor subtype-selective regulation, wherein the concerted actions of key regulators of somatotrope function would play divergent and dose-dependent effects.
\end{abstract}

Journal of Molecular Endocrinology (2004) 32, 437-448

\section{Introduction}

Somatostatin (SRIF), as its name implies, was first recognized as a neuroendocrine inhibitor of pituitary growth hormone (GH; somatotropin). However, since its discovery SRIF has been shown to inhibit also the release of thyrotropin, and to mediate the function of all pituitary cell types depending on the physiological/hormonal environment of the tissue donor (Patel 1999). Moreover, within the brain, SRIF acts as a classic neurotransmitter, while in the periphery SRIF produced in the gastrointestinal tract, kidney and lymphoid tissue acts as a paracrine and endocrine factor to mediate a wide array of functions (Reisine \& Bell 1995, Meyerhof 1998, Patel 1999, Benali et al. 
2000, Krantic 2000, Gsaba \& Dournaud 2001). The multiple actions of SRIF are believed to be transduced by the differential use of six G-protein coupled receptor subtypes (sst1, sst2A, sst2B, sst3, sst4 and sst5) encoded by five separate genes (sst1$5)$, all of which have been cloned in the human, rat and mouse (Reisine \& Bell 1995, Meyerhof 1998, Patel 1999, Baumeister \& Meyerhof 2000, Benali et al. 2000, Kraus et al. 2000, Gsaba \& Dournaud 2001). All six SRIF receptor subtypes are expressed within the pituitary gland. However, analysis of SRIF receptor subtype protein and mRNA levels within the pituitaries of rats, mice and humans demonstrates that sst2 and sst5 are the dominant receptor isoforms (Kumar et al. 1997). Also at a functional level, sst2 and sst5 play a dominant role in inhibition of GH release where sst2- and sst5specific receptor agonists are 1000-fold more effective in suppressing GH-releasing hormone (GHRH)-mediated GH release compared with sst1, sst3 and sst4 agonists (Shimon et al. 1997a,b, Rohrer et al. 1998). Nevertheless, other studies suggest an important role for sstl in the control of basal GH release (Kreienkamp et al. 1999).

In pigs, unlike other mammals studied to date, SRIF plays a dual role in controlling GH secretion from somatotropes (Castaño et al. 1996, Ramírez et al. 1997, 1998, 2002). Previous studies from our laboratory have shown that low (picomolar) doses of SRIF actually stimulate GH release from cultured porcine somatotropes, whereas higher (nanomolar) concentrations of the peptide inhibit GHRH-stimulated but not basal GH release (Ramírez et al. 1997, 1998, 2002). The stimulatory action of SRIF on GH release is believed to be mediated by stimulation of a cAMP intracellular signal transduction pathway, in that adenylyl cyclase inhibitors block this effect (Ramírez et al. 2002). Species-specific differences in SRIF actions could be due to differential expression and ligand-dependent regulation of the various SRIF receptor subtypes. There is solid evidence that SRIF can acutely and selectively regulate the function of each SRIF receptor subtype through ligand-dependent receptor desensitization, internalization and degradation (Meyerhof 1998, Patel 1999, Benali et al. 2000, Csaba \& Dournaud 2001). However, SRIF can also regulate its own receptor synthesis and this homologous regulation can be modified by heterologous signals via cross-talk of intracellular signaling pathways (Reisine \& Bell
1995, Meyerhof 1998, Patel 1999, Baumeister \& Meyerhof 2000, Benali et al. 2000, Kraus et al. 2000, Cisaba \& Dournaud 2001). Regulation of SRIF receptor gene expression by homo- and heterologous signals has been studied in different tissues and cell lines by using diverse technical approaches, including Northern blotting, RT-PCR, and heterologous and homologous transient transfection systems using SRIF receptor promoterdriven reporter plasmids (Reisine \& Bell 1995, Meyerhof 1998, Patel 1999, Baumeister \& Meyerhof 2000, Benali et al. 2000, Kraus et al. 2000, Csaba \& Dournaud 2001). These studies have revealed that a variety of signals, including SRIF, GHRH, glucocorticoids, cAMP-elevating agents, gonadal steroids and growth factors, differentially control the expression of SRIF receptors in the pituitary and in pituitary-derived cell lines (Bruno et al. 1994a,b, Reisine \& Bell 1995, Xu et al. 1995, Señaris et al. 1996, Djordjijevic et al. 1998, Kimura et al. 1998, Meyerhof 1998, Patel 1999, Baumeister \& Meyerhof 2000, Benali et al. 2000, Kraus et al. 2000, Park et al. 2000, 2002, Csaba \& Dournaud 2001). Nevertheless, very little is known on the regulation of SRIF receptor expression in species other than human, rat, and mouse.

Therefore, in the present study we sought to better understand the differential effects of SRIF on pig pituitary GH release by investigating the acute regulation of SRIF receptor expression by specifically focusing on the three SRIF receptor subtypes previously shown to be critical in GH regulation in other mammalian species, sst1, sst2 and sst5. However, of these SRIF receptor subtypes, only sst2 has been cloned in the pig (Matsumoto et al. 1994). To circumvent this problem, we used primer sets based on homologous regions of the rat, mouse and human sstl and sst5 genes, to PCR amplify and obtain partial sequence of the pig sstl and sst5 coding regions. With the published (Matsumoto et al. 1994) and new sequence data we developed and validated a multiplex RT-PCR assay that enabled the simultaneous assessment of the mRNA levels for porcine sst1, sst2 and sst5. Using this approach, we have studied the expression of these receptors in cultures of pig pituitary cells in response to treatment with SRIF, GHRH, ghrelin and forskolin, a receptor-independent activator of the cAMP pathway. The results obtained provide, for the first time, basic information on homologous 
and heterologous regulation of the expression of pig SRIF receptors, and demonstrate distinct patterns of response of each receptor subtype to the same signals.

\section{Materials and methods}

\section{Reagents}

Unless otherwise indicated, chemical products were purchased from Sigma Chemical Co. (St Louis, MO, USA) and tissue culture reagents and molecular biology reagents were obtained from GIBCO-BRL (Grand Island, NY, USA).

\section{Animals, cell dispersion and cell culture}

Prepubertal (4-6 month) female Large-White/ Landrace pigs were killed according to the principles and procedures outlined in the $\mathrm{NIH}$ Guide for the Care and Use of Laboratory Animals of the University of Illinois (Chicago, IL, USA). After killing, pituitaries were immediately excised and stored $(<15 \mathrm{~min}$ postmortem) in sterile cold $\left(4{ }^{\circ} \mathrm{C}\right)$ culture medium (Minimum Essential Medium; MEM) containing $0 \cdot 1 \% \mathrm{BSA}, 100 \mu \mathrm{g} / \mathrm{ml}$ streptomycin and $100 \mathrm{U} / \mathrm{ml}$ penicillin. At the laboratory, posterior lobes were removed and the anterior pituitaries were dispersed following an enzymatic and mechanical dispersion protocol described in detail previously (Aleppo et al. 1997). Cells were plated onto 12-well tissue culture plates at a density of 800000 cells/well in $1 \mathrm{ml} \alpha \mathrm{MEM}$ supplemented with $0.1 \%$ BSA and antibiotics supplemented with $10 \%$ fetal bovine serum. After 3 days of culture, medium was removed and cells were preincubated with fresh, serum-free medium for $1 \mathrm{~h}$ at $37^{\circ} \mathrm{C}$. Medium was then replaced with fresh media containing the test substances at the appropriate concentrations or the corresponding control vehicle, and incubated for an additional $4 \mathrm{~h}$ at $37^{\circ} \mathrm{C}$.

\section{RNA isolation}

Total RNA extraction was carried out using the Tri Reagent protocol (Molecular Research Center, Cincinnati, OH, USA). To increase the efficiency of the reverse transcriptase (RT) reaction the aqueous phase was further purified by extraction with phenol:chloroform:isoamyl alcohol (25:24:1; pH 5•2; Fisher Scientific, Pittsburgh, PA, USA). Following extraction the RNA was precipitated with isopropanol and the pellet washed with $70 \%$ ethanol, air dried, and resuspended in $10 \mathrm{mM}$ Tris-HCl, pH 7·6, 1 mM EDTA buffer. Concentration and purity of the RNA samples were estimated by UV spectroscopy at 260 and $280 \mathrm{~nm}$, and integrity confirmed by electrophoresis through $1 \%$ agarose gels stained with ethidium bromide.

\section{Partial sequencing of pig sst 1 and sst 5 and PCR primer design for sst1, sst2 and sst5}

Of the three porcine SRIF receptor subtypes analyzed in the present study, only pig sst2 had been previously cloned (Matsumoto et al. 1994). To obtain partial nucleotide sequences of pig sstl and sst5 coding sequences that would enable the development of a quantitative RT-PCR, we designed PCR primer sets within highly homologous areas of the human, rat and mouse sstl and sst5 coding sequences. Using these primers we PCR amplified cDNA obtained from pig pituitary RNA where product sizes and subsequent automated 3' and 5' sequencing (ABI PRISM 3100 Genetic Analyzer; Applied Biosystems, Foster City, CA, USA) demonstrated close similarity to the corresponding sequences in the homologous mammalian sst1 and sst5 receptors cDNA. Specifically, a fragment of $322 \mathrm{bp}$ was obtained for pig sstl (GenBank Accession No. AY138806) that encompasses from the $5^{\prime}$ end of transmembrane (TM) region 3 through the $5^{\prime}$ end of intracellular loop 3 . For pig sst5, we obtained a fragment of $201 \mathrm{bp}$ (GenBank Accession No. AY138807), comprising the $5^{\prime}$ end of intracellular loop 2 to the internal region of TM domain 5. These sequences were then used to design internal, pig-specific primers, which were selected on the basis of providing comparable annealing temperatures and compatible product size. Likewise, primers were designed for sst2 using the known sequence (Matsumoto et al. 1994; GenBank Accession No. D21338), and the specificity of the fragment amplified was confirmed by sequencing. The coding sequences of the SRIF subtype receptors amplified were: (i) sst1, from third to fifth TM region (TM3-TM5), (ii) sst2, from fifth to seventh TM region (TM5TM7), and (iii) sst5, from fourth to fifth TM region (TM4-TM5). Finally, porcine hypoxanthine 
Table 1 Sequence of primers employed for the multiplex RT-PCR assay of SRIF receptors with corresponding size of the fragments amplified and their GenBank Accession Numbers

\begin{tabular}{|c|c|c|c|}
\hline & Primer sequences $\left(5^{\prime} \rightarrow 3^{\prime}\right)$ & Size (bp) & $\begin{array}{l}\text { GenBank } \\
\text { Accession Number }\end{array}$ \\
\hline \multicolumn{4}{|l|}{ Receptor } \\
\hline sst1 & $\begin{array}{l}\text { Sense: CACCAGCATCTACTGTCTTAC } \\
\text { Antisense: AAAGTGTACAACACGAAGC }\end{array}$ & 258 & AY138806 \\
\hline sst2 & $\begin{array}{l}\text { Sense: TTCATTATCTACGCCTTCATCC } \\
\text { Antisense: GATTTGTCCTGCTTACTGTCAC }\end{array}$ & 422 & D21338 \\
\hline sst5 & $\begin{array}{l}\text { Sense: TGCACCCCCTTCGCTCTG } \\
\text { Antisense: CCAGCTGAGGTTGCAGGTGT }\end{array}$ & 149 & AY138807 \\
\hline HPRT & $\begin{array}{l}\text { Sense: TGAACGTCTTGCTCGAGATGTG } \\
\text { Antisense: TTATATCGCCCGTTGACTGGTC }\end{array}$ & 206 & U69731 \\
\hline
\end{tabular}

phosphoribosyltransferase (HPRT; GenBank Accession No. U69731) was selected as internal control and the appropriate primers were designed and tested, including the sequencing of the fragment amplified. (See Table 1 for specific primer sequences and PCR product sizes.)

\section{Multiplex RT-PCR of pituitary sst mRNA}

mRNA levels of sst1, sst2 and sst5 were assessed using semi-quantitative RT-PGR. First-strand cDNA for PCR was synthesized from $1 \mu \mathrm{g}$ total RNA by reverse transcription using random hexamer primers according to the Superscript Preamplification System for First Strand Synthesis (Life Technologies, Inc., St Louis, MO, USA). All PCR reactions were performed under the following conditions: an initial denaturing step of $10 \mathrm{~min}$ at $95{ }^{\circ} \mathrm{C}$ followed by 27 cycles of 1 min denaturation at $95{ }^{\circ} \mathrm{C}, 1 \mathrm{~min}$ annealing at $61{ }^{\circ} \mathrm{C}$, and $1 \mathrm{~min}$ extension at $72{ }^{\circ} \mathrm{C}$ with a $10 \mathrm{~min}$ final extension at $72{ }^{\circ} \mathrm{C}$. PCR products derived from RNA were verified by their absence in reactions performed without RT.

The PGR reactions were performed in a $50 \mu \mathrm{l}$ volume containing $2 \mu \mathrm{RT}$ reaction, $2 \mathrm{U}$ Taq Gold polymerase (Perkin-Elmer Corp., Branchburg, NJ, USA), $1 \times$ PCR buffer, $0.2 \mathrm{mM}$ deoxy-NTPs, $1.5 \mathrm{mM} \mathrm{MgCl}{ }_{2}$ and $5 \mu \mathrm{Ci}\left[\alpha-{ }^{32} \mathrm{P}\right]$ deoxy-CTP $(800$ $\mathrm{Ci} / \mathrm{mmol})$. The appropriate primer concentrations, $0.6 \mu \mathrm{M}$ sst 1 primers, $0.3 \mu \mathrm{M}$ sst 2 primers, $0.6 \mu \mathrm{M}$ sst5 primers and $0.04 \mu \mathrm{M}$ HPRT primers, were empirically determined to achieve a final signal that was comparable for all PGR products within each reaction and that would provide non-competitive and specific amplification for each PCR product. Consequently, this technique can only be used to compare the expression level of a single receptor type between experimental groups and not the relative expression levels between the various receptor subtypes.

PCR products $(20 \mu \mathrm{l})$ were separated on $5 \%$ polyacrylamide gel. Gels were dried on chromatography paper and exposed to a phosphorimage screen. The intensity of each band was visualized and analyzed using image analysis software (Molecular Dynamics, Inc., Sunnyvale, CA, USA), where band intensity is expressed in pixels. In order to control for variability in the amount of total RNA used in the RT reaction and the efficiency of conversion of RNA to cDNA, SRIF receptor subtype mRNA levels, within the same reaction, were normalized to the HPRT mRNA and expressed as a percentage of the vehicle-treated levels $(100 \%)$.

\section{Statistical analysis}

Data are expressed as means \pm S.E.M. from three independent experiments performed on different pituitary cell preparations. In each experiment, treatment groups were tested in triplicate. All comparisons were made between samples electrophoresed on the same gel. Statistical analysis was carried out using a one-way ANOVA, followed by a statistical test for multiple comparisons (Duncan's multiple range test and critical ranges) by use of the software package Statistica (StatSoft, Inc., Tulsa, OK, USA). Differences were considered significant at $P<0 \cdot 01$. 


\section{Results}

\section{Validation of the multiplex RT-PCR for quantification of mRNA levels of pig sst subtypes}

Application of an RT-PGR technique provides a rapid, reliable and sensitive means to measure mRNA levels of several gene products in the same sample. However, because of the exponential nature of the PCR, accuracy of this method is critically dependent on several variables, including PCR cycle number and the amount of starting mRNA of the sample (Zamorano et al. 1996, Aleppo et al. 1997). Hence, these parameters must be optimized and tightly

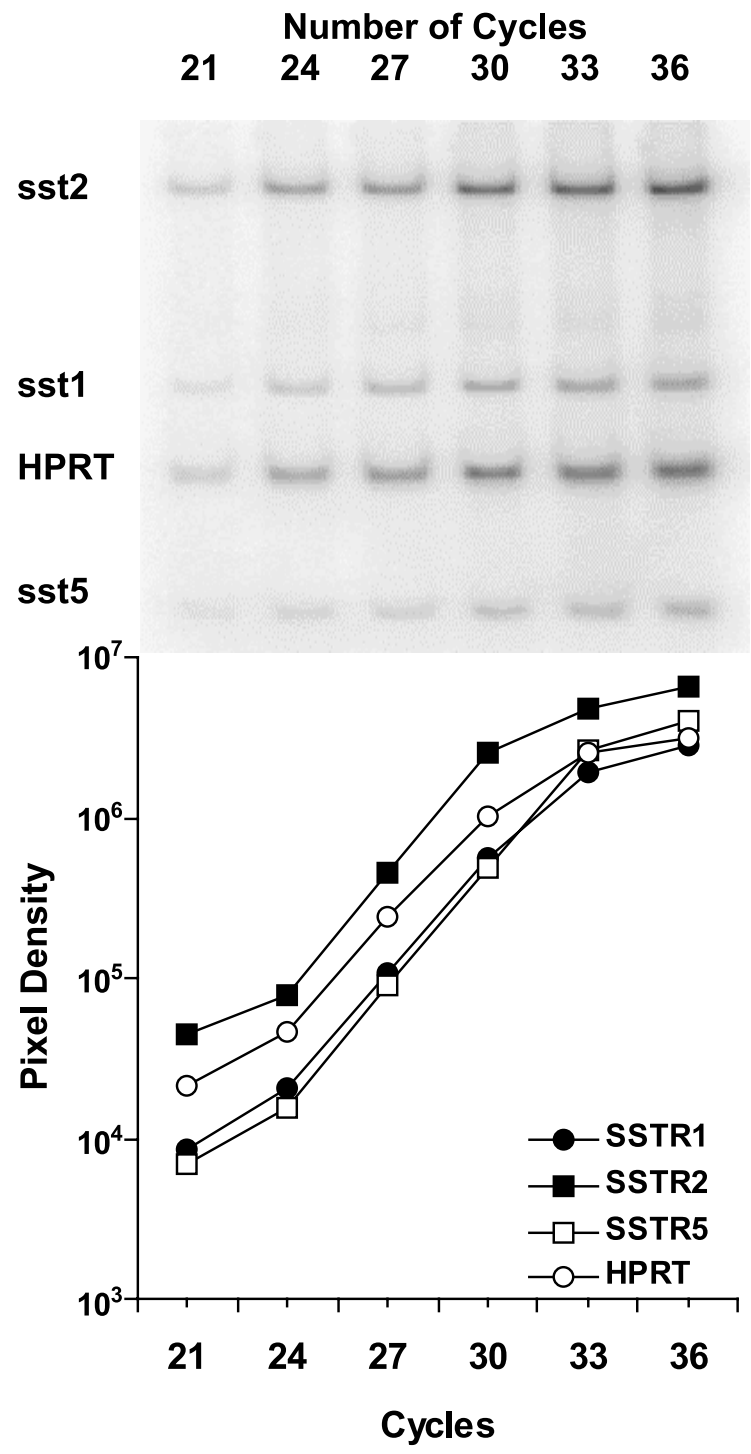

www.endocrinology.org controlled. The multiplex RT-PCR developed in this study amplified sst1, 2 and 5 and HPRT (a housekeeping gene (Foss et al. 1998)) transcripts from whole pituitary extracts in the same amplification reaction. To determine the cycle numbers that would correspond to the parallel amplification range of all PCR products within each reaction, PGR was performed between 21 and 36 cycles. All PCR products were amplified with similar efficiency between 24 and 30 cycles, as shown by the linear portions of the corresponding curves depicted in Fig. 1. Inasmuch as similar results were obtained in at least three independent experiments it can be assumed that: (i) there is no competition between primer sets; (ii) reagents are not limiting; and (iii) amplification efficiencies are similar for all transcripts within each reaction. To verify that the sst/HPRT ratio provides an accurate assessment of the level of sstl, sst2 and sst5 mRNA, varying volumes of the RT reaction representing 0.025$0 \cdot 15 \mu \mathrm{g}$ total RNA were added to the PCR reaction. Results showed that the ratios between sstl/HPRT, sst2/HPRT and sst5/HPRT remained constant in this concentration range (data not shown). It should also be noted that the expression level of HPRT represents an appropriate endogenous control since HPRT did not significantly vary between the various treatment groups in this study (data not shown). Accordingly, all subsequent PCR amplifications were performed with $0 \cdot 1 \mu \mathrm{g}$ total RNA equivalent $(2 \mu \mathrm{l}$ of the $\mathrm{RT}$ reaction) and at 27 cycles, which represents the midpoint of the linear portion of the curve.

Figure 1 Amplification kinetics of cDNA for pig pituitary SRIF receptor subtypes (sst1, sst2 and sst5) and an endogenous internal standard (HPRT) using multiplex RT-PCR. One microgram of total pituitary RNA was reverse transcribed using random hexamer priming. cDNA was amplified by PCR in a single sample, in the presence of radiolabeled $\left[\alpha-{ }^{32} \mathrm{P}\right]$ deoxy-CTP, using specific primers for sst1, sst2, sst5 and HPRT. Refer to Table 1 for specific primer sequences and product sizes. The radiolabeled PCR products were separated on a $5 \%$ polyacrylamide gel. The gel was dried on chromatography paper and exposed to a phosphorimage screen. The signal intensities (pixel densities) of the PCR products (upper panel) were measured by image analysis software. All PCR products were of the expected size. Amplifications of sst1, sst2, sst5 and HPRT were parallel between 24 and 30 cycles (lower panel). Similar results were obtained in two additional, separate experiments. Accordingly, all subsequent PCR amplifications were performed at 27 cycles. 


\section{Effects of SRIF on SRIF receptor subtype mRNA levels in pig pituitary cell cultures}

Having established a valid RT-PCR methodology to quantify pig sst mRNA levels, we first sought to ascertain the acute homologous regulation of sst gene expression. To this end, porcine pituitary cells were treated with two doses of SRIF (high, $10^{-7} \mathrm{M}$; and low, $10^{-13} \mathrm{M}$ ), which have been

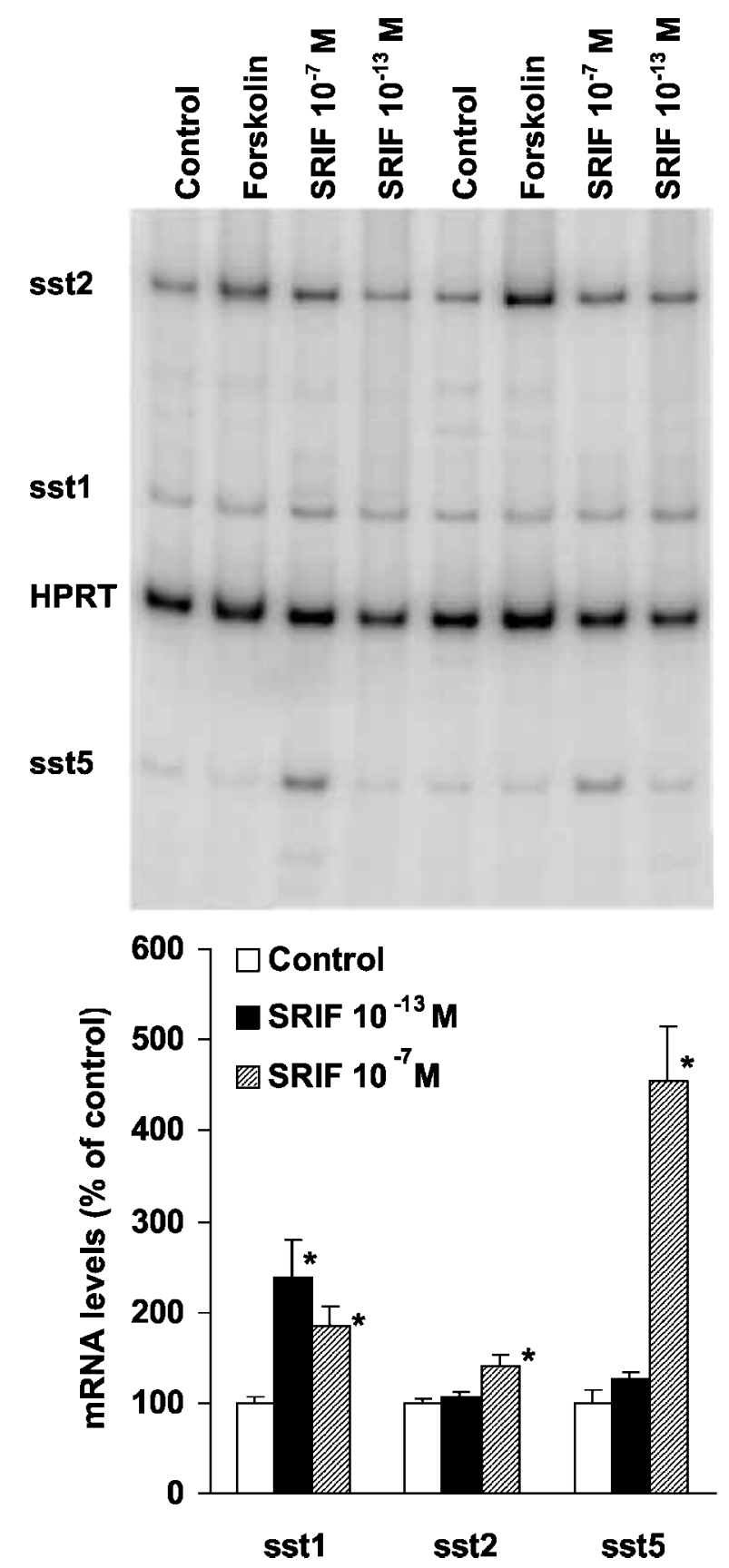

previously shown to evoke different GH secretory responses in porcine somatotropes (Ramírez et al. 1997, 1998, 2002). Specifically, these were a high SRIF dose that inhibits GHRH-induced GH release without affecting basal GH secretion, and a low SRIF dose that increases GH release in the absence of GHRH. Results from these experiments are presented in Fig. 2, showing a representative gel picture (top panel) and the averaged results of three independent experiments (bottom graph). As can be observed in Fig. 2, a 4 h treatment with $10^{-7} \mathrm{M}$ SRIF increased mRNA levels of sst1, sst2 and sst5 to 185,164 and $455 \%$ of vehicle-treated controls respectively. The low dose of SRIF also enhanced sst 1 mRNA levels $(239 \%)$ to values comparable with high-dose SRIF, but had no significant effect on sst2 and sst5 mRNA levels.

\section{Effects of forskolin on SRIF receptor subtype mRNA levels in cultured pig pituitary cells}

Since our laboratory has previously demonstrated that SRIF (at high and low doses) can stimulate cAMP production in a subpopulation of porcine pituitary somatotropes (Ramírez et al. 2002), it was of interest to determine if forskolin, a synthetic compound that increases cAMP levels by directly stimulating adenylyl cyclase activity, could mimic the effects of SRIF on SRIF receptor subtype expression. As shown in Fig. 2 (top, representative gel picture) and Fig. 3 (averaged results), treatment with forskolin $(10 \mu \mathrm{M} ; 4 \mathrm{~h})$ increased sstl and sst2 mRNA levels, without altering sst5 expression, suggesting that some but not all of the actions of SRIF on the expression of its own receptor subtypes may be mediated via activation of the

Figure 2 Effects of acute, in vitro SRIF treatment on mRNA levels of pig pituitary SRIF receptor subtypes sst1, sst2 and sst5. Dispersed pig pituitary cells were cultured for $4 \mathrm{~h}$ with two distinct SRIF doses (high, $10^{-7} \mathrm{M}$; or low, $10^{-13} \mathrm{M}$ ), and SRIF receptor subtype mRNA levels were determined by multiplex RT-PCR. The upper panel shows the image obtained in two representative experiments. Receptor-specific band intensities were determined and adjusted by the signal intensity for HPRT. The averaged results were then calculated and expressed as a percentage of vehicle-treated control levels (bottom panel; means \pm S.E.M.; $n=3$ separate experiments, each containing three wells/group per experiment). ${ }^{\star} P<0.01$ vs corresponding control. 


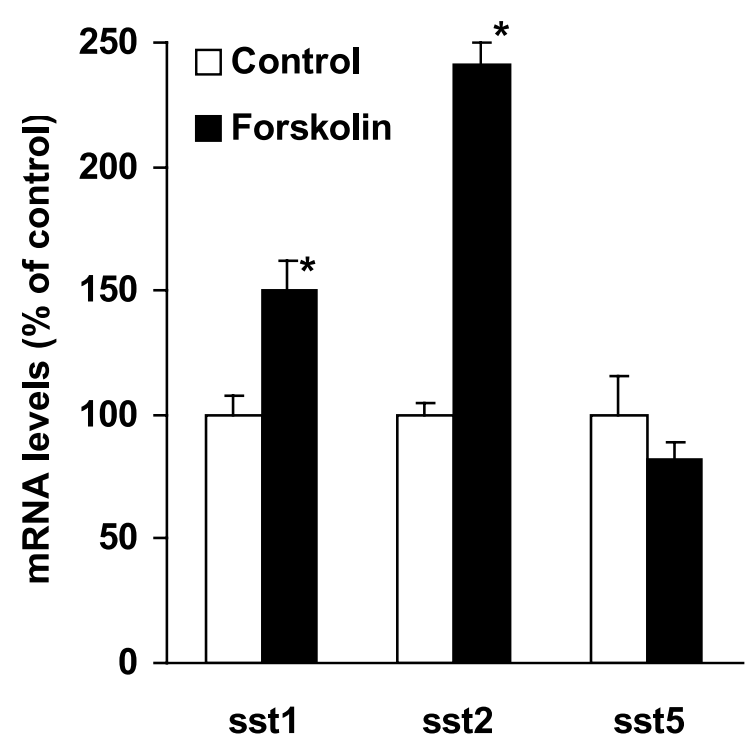

Figure 3 Effects of acute, in vitro treatment with the cAMP-elevating agent forskolin on mRNA levels of pig pituitary SRIF receptor subtypes sst1, sst2 and sst5. Dispersed pig pituitary cells were cultured for $4 \mathrm{~h}$ with forskolin $(10 \mu \mathrm{M})$, and receptor mRNA levels were determined by multiplex RT-PCR. Receptor-specific band intensities were adjusted by the signal intensity for HPRT. Results are expressed as a percentage of vehicle-treated control levels and represent the means \pm S.E.M. ( $n=3$ separate experiments, each containing three wells/group per experiment). ${ }^{*} P<0.01$ vs corresponding control.

cAMP/protein kinase A (PKA) intracellular signaling pathway.

\section{Effects of GHRH and ghrelin on SRIF receptor subtype mRNA levels in cultured pig pituitary cells}

As in other species, GHRH has been shown to stimulate GH release by increasing cAMP production in pig somatotropes (Ramírez et al. 1999). Additionally, we recently observed that ghrelin also augments cAMP and requires the activation of adenylyl cyclase and PKA to stimulate GH secretion from cultured pig pituitary cell cultures (Malagón et al. 2003). Hence, we reasoned that if cAMP were the exclusive regulator of SRIFmediated induction of sstl and sst2 mRNA levels, GHRH and ghrelin would have comparable effects. Acute treatment $(4 \mathrm{~h})$ of pig pituitary cell cultures with GHRH $\left(10^{-8} \mathrm{M}\right)$ and ghrelin $\left(10^{-6} \mathrm{M}\right)$ showed this was not the case. As

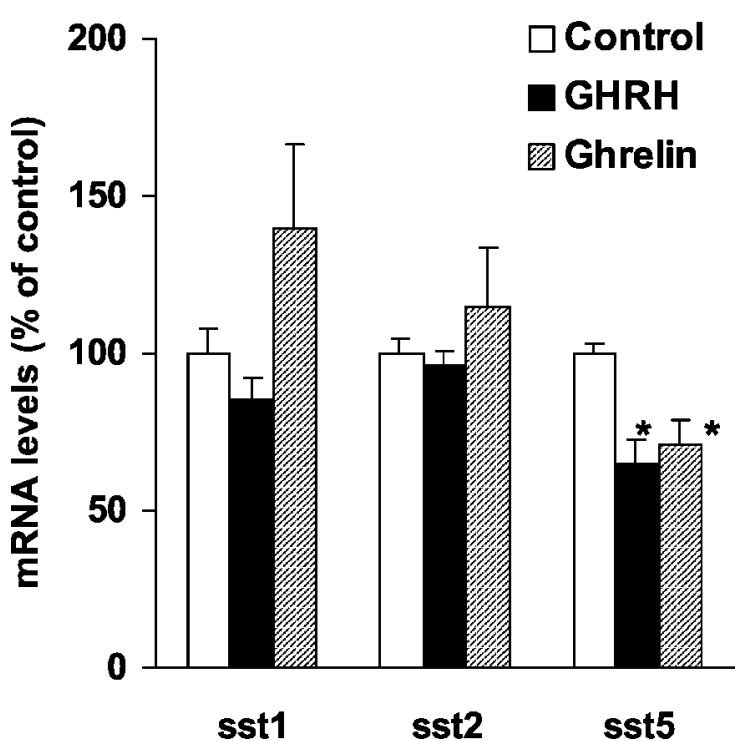

Figure 4 Expression of pig pituitary SRIF receptor subtypes sst1, sst2 and sst5 in response to acute GHRH or ghrelin treatment. After 3 days of culture, dispersed pig pituitary cells were incubated with $\mathrm{GHRH}$ $\left(10^{-8} \mathrm{M}\right)$ or ghrelin $\left(10^{-6} \mathrm{M}\right)$ for $4 \mathrm{~h}$, and SRIF receptor subtype mRNA levels were assessed by multiplex RT-PCR. Receptor-specific band intensities were adjusted by the signal intensity for HPRT. Results are expressed as a percentage of vehicle-treated control levels and represent the means \pm S.E.M. $(n=3$ separate experiments, each containing three wells/group per experiment). ${ }^{*} P<0.01$ vs corresponding control.

depicted in Fig. 4, GHRH and ghrelin reduced sst5 mRNA levels, but did not significantly modify the expression of sst1 and sst2.

\section{Discussion}

This report demonstrates that SRIF can upregulate sst1, sst2 and sst5 mRNA levels when applied to porcine pituitary cell cultures in nanomolar concentrations. The stimulatory actions of SRIF on its own receptor synthesis have also been reported using a rat pituitary cell line, $\mathrm{GH}_{3}$, where acute $(2 \mathrm{~h})$ and long-term $(>24 \mathrm{~h})$ treatment with SRIF $\left(10^{-6} \mathrm{M}\right)$ elevated sst1, sst3, sst4 and sst5 mRNA levels (Bruno et al. 1994a, Berelowitz et al. 1995). However, sst2 mRNA levels in the aforementioned study were only observed to increase following acute SRIF exposure, but decreased with prolonged exposure. Short-term SRIF (4 h, 1 and $100 \mathrm{nM}$ ) treatment also increased SRIF receptor mRNA levels in primary rat pituitary cell cultures 
but this increase was confined to the sst 3 and sst5 receptor subtypes (Park et al. 2002). In vivo, i.v. treatment with octreotide, an sst2/5-preferring SRIF receptor agonist, enhanced sstl and sst2 mRNA levels in the arcuate nucleus of the rat, while sst1 and sst2 mRNA levels of the pituitary were insensitive to treatment (Tannenbaum et al. 2001). Taken together, these results suggest that SRIF plays an overall stimulatory role on its own receptor synthesis; however, the regulation of specific receptor subtypes is dependent on the species, the tissue type, and the source of cells used (primary vs clonal cell lines).

Interestingly, a concentration of SRIF as low as $10^{-13} \mathrm{M}$, which stimulates $\mathrm{GH}$ secretion from cultured pig somatotropes (Ramírez et al. 1998), increased sst1 expression, but did not alter sst2 or sst5 mRNA levels. One can argue that the lack of an effect of low-dose SRIF on sst2 and sst5 mRNA levels may be explained by a lower sensitivity of these particular receptor subtypes to stimulation by their own ligand. An alternative explanation is that SRIF can activate distinct signaling mechanisms depending on the dose used, where the differential activation of these intracellular signaling pathways would have variable effects on SRIF receptor subtype expression. In support of the latter hypothesis, our laboratory has reported that SRIF differentially regulates the cAMP/PKA intracellular signaling in pig pituitary cell cultures depending on the dose used and the specific subpopulation of pituitary cells employed. At doses in the nanomolar range, SRIF inhibits GHRH-stimulated cAMPinitiated $\mathrm{GH}$ release in heterogeneous pig pituitary cell cultures (Ramírez et al. 2002), as observed in pituitary cell cultures from other mammalian species (Reisine \& Bell 1995, Giustina \& Veldhuis 1998, Meyerhof 1998, Patel 1999, Csaba \& Dournaud 2001). However, at doses in the picomolar range, SRIF stimulates GH release from pig pituitary cells (Ramírez et al. 1998). The stimulatory action of SRIF is attributed to a subpopulation of porcine somatotropes that accounts for over $40 \%$ of the total somatotrope population (Castaño et al. 1996, Ramírez et al. 1997, 2002). This subpopulation responds to both high- and low-dose SRIF treatment by an increase in cAMP accumulation. In fact, the stimulatory effect of SRIF on GH release from these cells can be blocked by inhibitors of adenylyl cyclase activity (Ramírez et al. 2002).
In the present study we sought to determine if increasing intracellular cAMP by forskolin activation of adenylate cyclase could mimic the stimulatory actions of SRIF on its own receptor expression in porcine pituitary cultures. As with high-dose SRIF, forskolin augmented mRNA levels of sst1 and sst2, but did not alter sst5 expression, suggesting sst1 and sst2 gene expression or mRNA stability is enhanced by a cAMP-dependent pathway, whereas SRIF stimulation of sst5 expression is mediated by a cAMP-independent mechanism. In support of the cAMP-dependent regulation of pituitary sst1 and sst2 expression, similar results have been reported in primary rat pituitary cell cultures; however, in this species, forskolin suppressed sst5 mRNA levels, as well as those for sst3 and sst4 (Park et al. 2000). Forskolin has also been shown to increase the expression of sst2 in AtT-20 cells, a mouse corticotrope cell line (Patel et al. 1993). However, forskolin failed to alter the activity of a human sst2 promoter-driven reporter plasmid transfected in the rat pituitary cell line, $\mathrm{GH}_{4} \mathrm{C}_{1}$ (Petersenn et al. 1999). In the latter study, it is difficult to determine if the absence of a forskolin effect is due to species-dependent regulation of this SRIF receptor subtype or due to the lack of the appropriate regulatory elements in the heterologous promoter/reporter system. To date, CREs have been shown to be located in promoter regions of the human (Petersenn et al. 1999) and mouse (Woltje et al. 1998, Kraus et al. 2000) sst2 genes and rat sst3 gene (Glos et al. 1998, Baumeister \& Meyerhof 2000), suggesting cAMP can regulate gene transcription of at least some SRIF receptor subtypes, by activation of cAMP-mediated PKA phosphorylation and binding of the CREB transcription factor (Mayr \& Montminy 2001).

The inability of forskolin to mimic the stimulatory actions of SRIF on sst5 mRNA levels suggests that SRIF enhanced the expression of this SRIF receptor subtype via a cAMP-independent pathway. It is interesting to note that the cAMP-dependent regulation of sst5 appears to be the most varied among experimental models. In the rat, forskolin was shown to inhibit sst5 mRNA levels (Park et al. 2000), while in a transient transfection system dibutyryl cAMP increased the activity of a human sst5 promoter/reporter construct in GH3 cells, a rat pituitary cell line (Greenwood et al. 1994). Of the sst5 promoter regions examined (human (Greenwood et al. 1994, 
Petersenn et al. 2002a), mouse (Gordon et al. 1999)) none has been shown to contain CREs, providing further evidence in favor of a cAMP-independent (or, at least, CRE-independent) regulatory mechanism possibly involving a yet to be identified intracellular signaling pathway. Clues to this alternative mechanism may be provided by the evidence generated in the pig, where we have observed that SRIF activates phospholipase C (PLC) signaling in a subpopulation of porcine pituitary somatotropes, although this activation does not seem to influence SRIF-induced GH release (Ramírez et al. 2002). Taking into account the well-established link between PLC and protein kinase $\mathrm{G}(\mathrm{PKG})$ activation, a direct regulation of sst5 gene expression by $\mathrm{PLC} / \mathrm{PKC}$ might be envisioned given the fact that the mouse sst5 promoter (Gordon et al. 1999) contains multiple AP-1 (AP, activator protein) sites while the human sst5 promoter contains both AP-1 and AP-2 sites (Greenwood et al. 1994). AP-1 and AP-2 sites have also been identified on the human sst4 (Petersenn et al. 2002b), and rat sst1 and sst3 promoters (Hauser et al. 1994, Glos et al. 1998). These response elements have been shown to be the site of c-Fos/Jun heterodimer binding and transcriptional regulation of other genes activated by phorbol ester stimulation of PKG (Karin et al. 1997). In line with this concept, activation of $\mathrm{PKG}$ via phosphoinositide 3-kinase by SRIF in the A431 cervical carcinoma cell line results in increased signaling through the kinases Erk/MAPK (Stetak et al. 2001), which are functionally linked to transcriptional activation via AP-1 sites (Karin et al. 1997). Nevertheless, it should also be noted that cAMP can activate this same pathway (Gutkind 2000), an example of cross-talk between ligand-activated G-protein intracellular signaling pathways.

In an attempt to better understand the relative contribution of ligand/receptor activation of cAMP-dependent and -independent pathways to the regulation of pig SRIF receptor subtype expression, we examined the effects of GHRH and ghrelin in this regard. In the pig, as in other mammals studied to date, GHRH acutely stimulates cAMP production, which is required for maximal GH release (Giustina \& Veldhuis 1998, Ramírez et al. 1999). In addition, ghrelin also raises cAMP and activates both cAMP/PKA and $\mathrm{PLC} / \mathrm{PKG}$ intracellular signaling in pig pituitary cell cultures and both pathways appear to be required for maximal GH release (Malagón et al. 2003). Despite the ability of both GHRH and ghrelin to activate a cAMP-dependent cascade in the pig pituitary, these two GH regulatory peptides did not mimic the actions of SRIF and forskolin on SRIF receptor subtype mRNA levels in the present study. In fact, both GHRH and ghrelin suppressed sst5 mRNA levels without significantly altering sst1 and sst2 expression. The stark contrast between the actions of SRIF and forskolin vs GHRH and ghrelin on SRIF receptor mRNA levels brings into question the simplified view of one intracellular signaling pathway equals one action. The divergent effects of peptides that stimulate the same intracellular signaling systems within the same cell may be explained by intracellular compartmentalization of specific ligand/receptor signaling events, where particular receptor subtypes are isolated to microdomains of the cell, and their activation of the same intracellular signal can lead to opposite actions depending on its relative 'position' within the cell (Sim \& Scott 1999, Schwartz 2001, Cordeaux \& Hill 2002). Another possibility to explain the divergent effects of SRIF, GHRH and ghrelin on SRIF receptor expression may be that they are due to activation of yet to be identified intracellular signaling pathways which may act alone or in combination with known signaling events to mediate SRIF receptor expression.

As with the species-dependent effects of SRIF on its own receptor expression, our data generated using pig pituitaries make it clear that heterologous regulation of sst1, sst 2 and sst 5 expression are also species-dependent. In contrast to the exclusive inhibitory actions of GHRH and ghrelin on pig sst5 expression, in the rat GHRH increases sst 1 and sst2 mRNA levels and suppresses sst5 mRNA levels in vivo and in vitro, while L-692, 585, a synthetic GHS-R ligand, had no effect (Park et al. 2000). The effects of GHRH on SRIF receptor subtype expression in the rat are thought to be mediated by cAMP, since forskolin mimicked the effects of GHRH in vitro (Park et al. 2000). However, in the present study using pig pituitary cell cultures, a direct correlation between GHRH and forskolin actions on SRIF receptor expression was not observed, thereby bringing into question the simple interpretation of the rat data.

The ultimate question is: what is the physiological impact of homologous and heterologous regulation of pituitary SRIF receptor level? With 
respect to homologous regulation of SRIF actions, Presky \& Schonbrunn (1988) and Berelowitz et al. (1995) reported that pretreatment of the rat pituitary cell lines for $24 \mathrm{~h}$ doubled SRIF receptor numbers as assessed by radiolabeled ligand binding without altering receptor affinity. The increase in ligand binding observed in these studies is likely due to stabilization of the SRIF receptor protein on the cell surface and not due to new receptor synthesis, in that cycloheximide, a protein synthesis inhibitor, did not disrupt the stimulatory effect of SRIF on subsequent ligand binding (Presky \& Schonbrunn 1988). Although new receptor synthesis does not appear to play a role in SRIF-mediated upregulation of its own receptors in pituitary cell lines, we cannot exclude that this mechanism operates in primary pituitary cell cultures. Nonetheless, an upregulation of receptor synthesis or receptor protein stability may be critical in counteracting the well-characterized rapid internalization and/or desensitization by phosphorylation of SRIF receptors following ligand binding (Reisine \& Bell 1995, Meyerhof 1998, Patel 1999, Csaba \& Dournaud 2001). Conversely, downregulation of SRIF receptor expression by the GH-stimulatory peptides, GHRH and ghrelin, may act to ultimately augment their actions, because SRIF, at high doses, is a well-characterized inhibitor of both GHRH (Ramírez et al. 1998) and ghrelin (Malagón et al. 2003) function in pigs, as in other species (Reisine \& Bell 1995, Giustina \& Veldhuis 1998, Meyerhof 1998, Patel 1999, Csaba \& Dournaud 2001, Yamazaki et al. 2002), most likely through its well-known opposing actions on adenylyl cyclase activity and calcium channel activation (reviewed in Giustina \& Veldhuis 1998, Meyerhof 1998, Patel 1999).

In conclusion, this study demonstrates that pig pituitary sst1, sst2 and sst5 respond differentially to the acute actions of SRIF, GHRH and ghrelin and, unlike in other species studied to date, some of these responses do not appear to be mediated via cAMP. Accordingly, it seems reasonable to propose that the expression of SRIF receptors in pig pituitary cells is under a complex, species-specific and receptor subtype-selective regulation by $\mathrm{GH}$ regulatory peptides that activate G-protein coupled receptor intracellular signaling cascades. Furthermore, given the distinct pattern of response of the three SRIF receptor subtypes to SRIF, GHRH and ghrelin, it seems highly unlikely that sst1, sst2 and sst5 convey the same signals or exert identical biological effects in response to SRIF in porcine somatotropes. The multiplex RT-PCR assay developed herein to measure changes in SRIF receptor subtype expression, coupled with studies underway in our laboratory to clone and characterize all of the genes encoding pig SRIF receptor subtypes, paves the way to investigate new aspects of their expression (long-term changes, metabolic control and role of sex steroids), and will thus provide novel information to help understand their distinct regulation, and the precise signaling mechanisms underlying such control.

\section{Acknowledgements}

The authors wish to thank Ms Geraldine A Amargo for helpful technical assistance. Support for this study was provided by grants CVI0139 (Plan Andaluz de Investigación, Junta de Andalucía, Spain), IFD97-0582 and PB97-0454 (Ministerio de Educación y Cultura, Spain), BFI-2000-0872 and BFI-2001-2007 (Ministerio de Ciencia y Tecnología-FEDER, Spain) (to M M M and J P G) and NIH-DK30667 (to R D K). Presented, in part, at the 83rd Annual Meeting of The Endocrine Society, Denver, Colorado, USA, 2001.

\section{References}

Aleppo G, Moskal SF, De Grandis PA, Kineman RD \& Frohman LA 1997 Homologous down-regulation of growth hormonereleasing hormone receptor messenger ribonucleic acid levels. Endocrinology 138 1058-1065.

Baumeister H \& Meyerhof W 2000 Gene regulation of somatostatin receptors in rats. Fournal of Physiology, Paris 94 167-177.

Benali N, Ferjoux G, Puente E, Buscail L \& Susini C 2000 Somatostatin receptors. Digestion 62 (Suppl 1) 27-32.

Berelowitz M, Xu Y, Song J \& Bruno JF 1995 Regulation of somatostatin receptor mRNA expression. CIBA Foundation Symposium 1995 111-126.

Bruno JF, Xu Y \& Berelowitz M 1994a Somatostatin regulates somatostatin receptor subtype mRNA expression in GH3 cells. Biochemical and Biophysical Research Communications 202 1738-1743.

Bruno JF, Xu Y, Song J \& Berelowitz M $1994 b$ Pituitary and hypothalamic somatostatin receptor subtype messenger ribonucleic acid expression in the food-deprived and diabetic rat. Endocrinology 135 1787-1792.

Castaño JP, Torronteras R, Ramírez JL, Gribouval A, Sánchez-Hormigo A, Ruiz-Navarro A \& Gracia-Navarro F 1996 Somatostatin increases growth hormone $(\mathrm{GH})$ secretion in a subpopulation of porcine somatotropes: evidence for functional and morphological heterogeneity among porcine GH-producing cells. Endocrinology 137 129-136. 
Cordeaux Y \& Hill SJ 2002 Mechanisms of cross-talk between G-protein-coupled receptors. Neurosignals 11 45-57.

Csaba Z \& Dournaud P 2001 Cellular biology of somatostatin receptors. Neuropeptides 35 1-23.

Djordjijevic D, Zhang J, Priam M, Viollet C, Gourdji D, Kordon C \& Epelbaum J 1998 Effect of 17 beta-estradiol on somatostatin receptor expression and inhibitory effects on growth hormone and prolactin release in rat pituitary cell cultures. Endocrinology $\mathbf{1 3 9}$ $2272-2277$.

Foss DL, Baarsch MJ \& Murtagh MP 1998 Regulation of hypoxanthine phosphoribosyltransferase glyceraldehyde-3phosphate dehydrogenase and beta-actin mRNA expression in porcine immune cells and tissues. Animal Biotechnology 9 $67-78$.

Giustina A \& Veldhuis JD 1998 Pathophysiology of the neuroregulation of growth hormone secretion in experimental animals and the human. Endocrine Reviews 19 717-797.

Glos M, Kreienkamp HJ, Hausmann H \& Richter D 1998 Characterization of the $5^{\prime}$-flanking promoter region of the rat somatostatin receptor subtype 3 gene. FEBS Letters 440 33-37.

Gordon DF, Woodmansee WW, Lewis SR, James RA, Wood WM \& Ridgway EC 1999 Cloning of the mouse somatostatin receptor subtype 5 gene: promoter structure and function. Endocrinology 140 5598-5608.

Greenwood MT, Panetta R, Robertson LA, Liu J-L \& Patel YC 1994 Sequence analysis of the $5^{\prime}$-flanking promoter region of the human somatostatin receptor 5. Biochemical and Biophysical Research Communications 205 1883-1890.

Gutkind JS 2000 Regulation of mitogen-activated protein kinase signaling networks by G protein-coupled receptors. Science's STKE 2000 RE1.

Hauser F, Meyerhof W, Wulfsen I, Schonrock C \& Richter D 1994 Sequence analysis of the promoter region of the rat somatostatin receptor subtype 1 gene. FEBS Letters 345 225-228.

Karin M, Liu Z \& Zandi E 1997 AP-1 function and regulation. Current Opinion in Cell Biology 9 240-246.

Kimura N, Tomizawa S, Arai KN \& Kimura N 1998 Chronic treatment with estrogen up-regulates expression of sst2 messenger ribonucleic acid (mRNA) but down-regulates expression of sst5 mRNA in rat pituitaries. Endocrinology 139 1573-1580.

Krantic S 2000 Peptides as regulators of the immune system: emphasis on somatostatin. Peptides 21 1941-1964.

Kraus J, Woltje M, Schonwetter N \& Hollt V 2000 Gene structure and regulation of the somatostatin receptor type 2. Foumal of Physiology, Paris 94 199-204.

Kreienkamp HJ, Akgun E, Baumeister H, Meyerhof W \& Richter D 1999 Somatostatin receptor subtype 1 modulates basal inhibition of growth hormone release in somatotrophs. FEBS Letters $\mathbf{4 6 2}$ $464-466$.

Kumar U, Laird D, Srikant CB, Escher E \& Patel YC 1997 Expression of the five somatostatin receptor (SSTR1-5) subtypes in rat pituitary somatotrophs: quantitative analysis by double-layer immunofluorescence confocal microscopy. Endocrinology 138 4473-4476.

Malagón MM, Luque RM, Ruiz-Guerrero E, Rodríguez-Pacheco F, García-Navarro S, Gracia-Navarro F \& Castaño JP 2003 Intracellular signaling mechanisms mediating ghrelin-stimulated growth hormone release in somatotropes. Endocrinology 144 $5372-5380$

Matsumoto K, Yokogoshi Y, Fujinaka Y, Zhang C \& Saito S 1994 Molecular cloning and sequencing of porcine somatostatin receptor 2. Biochemical and Biophysical Research Communications 199 298-305.

Mayr B \& Montminy M 2001 Transcriptional regulation by the phosphorylation-dependent factor CREB. Nature Reviews. Molecular Cell Biology 2 599-609.
Meyerhof W 1998 The elucidation of somatostatin receptor functions: a current view. Reviewes of Physiology, Biochemistry, and Pharmacology 133 55-108.

Park S, Kamegai J, Johnson TA, Frohman LA \& Kineman RD 2000 Modulation of pituitary somatostatin receptor subtype (sst1-5) messenger ribonucleic acid levels by changes in the growth hormone axis. Endocrinology 141 3556-3563.

Park S, Kamegai J \& Kineman RD 2003 Role of glucocorticoids in the regulation of pituitary somatostatin receptor subtype (sstl-5) mRNA levels: evidence for direct and somatostatin mediated effects. Neuroendocrinology 78 163-175.

Patel YC 1999 Somatostatin and its receptor family. Frontiers in Neuroendocrinology 20 157-198.

Patel YC, Greenwood MT, Kent G, Panetta R \& Srikant CB 1993 Multiple gene transcripts of the somatostatin receptor SSTR2: tissue selective distribution and cAMP regulation. Biochemical and Biophysical Research Communications 192 288-294.

Petersenn S, Rasch AC, Presch S, Beil FU \& Schulte HM 1999 Genomic structure and transcriptional regulation of the human somatostatin receptor type 2. Molecular and Cellular Endocrinology 157 75-85.

Petersenn S, Rasch AC, Böhnke C \& Schulte HM $2002 a$ Identification of an upstream pituitary-active promoter of human somatostatin receptor subtype 5. Endocrinology 143 2626-2634.

Petersenn S, Rasch AC, Presch S, Beil FU \& Schulte HM $2002 b$ Characterization of the human somatostatin receptor type 4 promoter. Molecular and Cellular Endocrinology 188 75-83.

Presky DH \& Schonbrunn A 1988 Somatostatin pretreatment increases the number of somatostatin receptors in GH4C1 pituitary cells and does not reduce cellular responsiveness to somatostatin. Fournal of Biological Chemistry 263 714-721.

Ramírez JL, Torronteras T, Castaño JP, Sánchez-Hormigo A, Garrido JC, García-Navarro S \& Gracia-Navarro F 1997 Somatostatin plays a dual, stimulatory/inhibitory role in the control of growth hormone secretion by two somatotrope subpopulations from porcine pituitary. Fournal of Neuroendocrinology 9 841-848.

Ramírez JL, Castaño JP \& Gracia-Navarro F 1998 Somatostatin at low doses stimulates growth hormone release from intact cultures of porcine pituitary cells. Hormone and Metabolic Research $\mathbf{3 0}$ $175-177$

Ramírez JL, Castaño JP, Torronteras R, Martínez-Fuentes AJ, Frawley LS, García-Navarro S \& Gracia-Navarro F 1999 Growth hormone $(\mathrm{GH})$-releasing factor differentially activates cyclic adenosine $3^{\prime}, 5^{\prime}$-monophosphate- and inositol phosphate-dependent pathways to stimulate $\mathrm{GH}$ release in two porcine somatotrope subpopulations. Endocrinology 140 1752-1759.

Ramírez JL, Gracia-Navarro F, García-Navarro S, Torronteras R, Malagón MM \& Castaño JP 2002 Somatostatin stimulates GH secretion in two porcine somatotrope subpopulations through a cAMP-dependent pathway. Endocrinology 143 889-897.

Reisine T \& Bell GI 1995 Molecular biology of somatostatin receptors. Endocrine Reviews 16 427-443.

Rohrer SP, Birzin ET, Mosley RT, Berk SC, Hutchins SM, Shen DM, Xiong Y, Hayes EC, Parmar RM, Foor F et al. 1998 Rapid identification of subtype-selective agonists of the somatostatin receptor through combinatorial chemistry. Science 282 737-740.

Schwartz JH 2001 The many dimensions of cAMP signaling. PNAS 98 13482-13484.

Señaris RM, Lago F \& Diéguez C 1996 Gonadal regulation of somatostatin receptor 1,2 and 3 mRNA levels in the rat anterior pituitary. Brain Research. Molecular Brain Research 38 171-175.

Shimon I, Taylor JE, Dong JZ, Bitonte RA, Kim S, Morgan B, Coy DH, Culler MD \& Melmed S 1997a Somatostatin receptor subtype specificity in human fetal pituitary cultures. Differential role of SSTR2 and SSTR5 for growth hormone, 
thyroid-stimulating hormone, and prolactin regulation. Foumal of Clinical Investigation 99 789-798.

Shimon I, Yan X, Taylor JE, Weiss MH, Culler MD \& Melmed S $1997 b$ Somatostatin receptor (SSTR) subtype-selective analogues differentially suppress in vitro growth hormone and prolactin in human pituitary adenomas. Novel potential therapy for functional pituitary tumors. Fournal of Clinical Investigation $\mathbf{1 0 0}$ 2386-2392.

Sim AT \& Scott JD 1999 Targeting of PKA, PKC and protein phosphatases to cellular microdomains. Cell Calcium 26 209-217.

Stetak A, Csermely P, Ullrich A \& Keri G 2001 Physical and functional interactions between protein tyrosine phosphatase alpha, PI 3-kinase, and PKCdelta. Biochemical and Biophysical Research Communications 288 564-572.

Tannenbaum GS, Turner J, Guo F, Videau C, Epelbaum J \& Beaudet A 2001 Homologous upregulation of sst2 somatostatin receptor expression in the rat arcuate nucleus in vivo. Neuroendocrinology $7433-42$.
Woltje M, Kraus J \& Hollt V 1998 Identification of a functional $3^{\prime}, 5^{\prime}$-cyclic adenosine monophosphate response element within the second promoter of the mouse somatostatin receptor type 2 gene. FEBS Letters 440 107-110.

Xu Y, Berelowitz M \& Bruno JF 1995 Dexamethasone regulates somatostatin receptor subtype messenger ribonucleic acid expression in rat pituitary GH4C1 cells. Endocrinology 136 5070-5075.

Yamazaki M, Nakamura K, Kobayashi H, Matsubara M, Hayashi Y, Kangawa K \& Sakai T 2002 Regulational effect of ghrelin on growth hormone secretion from perifused rat anterior pituitary cells. Fournal of Neuroendocrinology 14 156-162.

Zamorano PL, Mahesh VB \& Brann DW 1996 Quantitative RT-PCR for neuroendocrine studies. A minireview. Neuroendocrinology 63 397-407.

Received in final form 21 November 2003 Accepted 31 December 2003 